\title{
MARGARET STORM JAMESON AND THE SPANISH CIVIL WAR: THE FIGHT FOR HUMAN VALUES
}

\author{
JENNIFER BIRKETT \\ University of Birmingham
}

\begin{abstract}
Spain is not generally thought of as a significant theme in Jameson's writing, or her political formation. But careful study of her life and writing discloses numerous connections to the country from the early 1930s onwards, and No Victory for the Soldier (1938), the novel she published under the pseudonym of James Hill, in the 1930s, closes with a lengthy section on the Spanish Civil War. The tragic heroism of the Republic at war provides the ideal context for Jameson's exploration of the capacity of modernist art, or rather, modernist artists (the Auden generation) to speak in the name of the future of the common man. Spain, and especially the Basque country, fighting the fascist war machine, is one of the last repositories of humane living and European values: reason, justice, bumanity and decency.
\end{abstract}

"Does this mean anything to you?" (Hill 1939: 341)

Through the mouth of Sergeant Derio, the Basque professor of philosophy waiting for the German and Italian bombs to fall on Bilbao, Storm Jameson expressed the hopes pinned on Spain and its revolution. Here was the last opportunity of seeing the values she nostalgically assigned to pre-industrial England enshrined in the making of modern, metropolitan Europe. As Derio tells John Knox, the musician helping to man the Republican field hospitals:

"Here we still cared more for human beings than for anything they can make or possess. All our values were human ones. [...] We knew - even those of us who lived in the city knew - many things about the earth and the sea. [...] A poor 
man with us was as good as a man with money and a large house. We were free. We lived. We had a way of living; it has been the same for hundreds of years, but it was new every year. Every spring, every harvest. [...]" He looked angrily at Knox. "Does this mean anything to you?"

"Why did I come here?" Knox said softly. (Hill 1939: 341)

Spain is not generally thought of as a significant theme in Jameson's writing, or her political formation. Of European countries, France was for her a shrine of lost Englishness, and Czechoslovakia, the place of England's most shameful treachery. The novel which treats the Spanish Civil War in most detail, No Victory for the Soldier (1938), was not written in her own name, but under the pseudonym James Hill. This, it might be conjectured, was because the book was an experiment in form and content that was very different from the documentary fiction in which she had at last established her reputation in the 1930s. In political terms, it is harder to establish her motives. As she was writing the book, the consequences of English and French policies of non-interventionism in Europe were coming home to roost, and Hitler was reaching out to claim more of Europe's territories. In 1936, she had published In the Second Year, her dystopic vision of England in the aftermath of a fascist coup, and she may have been reluctant to advertise further, under her own name, Britain's weakness and the fascist sympathies of many in its establishment. She may have thought that the apparent rallying of another writer to the cause of resistance to fascism, in the name of popular democracy, would increase the impact of the message. She may have been reluctant to be seen in open sympathy with the Spanish Communists fighting against the rebels. This was certainly something she was reluctant to acknowledge in the Cold War years. In her autobiography, Journey from the North, composed in the early 1960s, all she says of No Victory for the Soldier is that it is "the story of John Knox from the day when, a Busoni of seven, he played in his first concert, to the day when he was killed in the Spanish civil war, and an effort at a portrait of the 1930s, with a great many characters and a great many scenes in England and Europe" (Jameson 1984a: I, 408). That summary also does little justice to the central preoccupation of the novel: Jameson's double commitment, as intellectual and socialist, to finding a form that will ally the energies of modern European cities to the deep-rooted knowledge and community spirit embedded in Europe's diverse landscapes. This form, she feels, will come from the perspective of common men and women, and express the desire to build a new kind of future, in their name.

James Hill's story expresses the longing of the liberal intellectuals of the 1930s to make a fresh start in the name of equality and justice, encompassing the death of the old world, and the Old Guard, without cutting all connections to the past. 
It also charts their recognition of the futility of such ambitions, leading both to the necessary murder and the necessary failure. Such pessimism was always part of Jameson's vision: "There were moments when it seemed [...] that the whole tale of Europe might be compressed into one picture of a peasant dead across his own shattered threshold" (Jameson 1928: 290).

\section{THE SOCIALIST ROAD TO EUROPE}

The socialist enthusiasm that drove Jameson, from her schooldays at Scarborough Grammar School, was kept burning by a proximity to the lives of the poor that was not experienced by many women writers of her time. At University in Leeds, in the early 1910s, she had taken food to striking workers' families. As a young woman in her first marriage, with a feckless husband and a new baby, she herself lived in poverty in Liverpool Garden Suburb. Her novels are full of vignettes of the (usually) quiet desperation of lives lived on the edge of destitution. Her antagonism to fascism was driven equally by the challenge it posed to freedom of thought, and the damage it inflicted on the lives of ordinary people.

But she came from a generation that before the First World War was turned in on its own country's social and political concerns. It was in the early 1930s that events in Europe first began to preoccupy her, and from her autobiography, it appears that Central and Eastern Europe were then her primary concern. Certainly, the problems of Berlin were the first to become part of her own direct experience. In the Autumn of 1931, in Scarborough at the "dispiriting" Labour Party Conference following the catastrophic election of 27 October 1931, when Ramsay Macdonald and his National Coalition were returned to power with a landslide, she met Lilo Linke, from East Berlin, an ardent Social Democrat (Jameson 1984a: I, 270). ${ }^{1}$ In the early months of 1932 (I, 266-282), Lilo accompanied Jameson and her second husband, the historian Guy Chapman, as they toured a Berlin in the throes of the election that put Hindenburg in power, and introduced them to her young Social Democrat and Communist activist friends. In 1933 came another dispiriting Labour Party conference, which brought home to Jameson the indifference of British Labour leaders to events on the Continent. In Hastings, sitting alongside the pacifist Philip Noel-Baker, and voting with him for workers'

1. Ramsay Macdonald's Government resigned 24th August 1931, after the Cabinet split on his proposal to balance the budget with a $10 \%$ cut in unemployment benefit. On 25 th August, he formed a National Coalition Government, pushed through his budget, and with Philip Snowden and J. P. Thomas was subsequently expelled from the Labour Party. 
control in factories, she watched Arthur Henderson turn away requests for help from beleaguered Trades Unionists in Berlin (I, 321-322).

From April 1932 to December 1933 she was reviewing, unpaid, for A. R. Orage's New English Weekly. Her widening perspectives will have been reinforced by an article by Philip Mairet, the advocate of European integration, published in June 1933, on A League of Minds, the first book produced by Paul Valéry's consortium, the International Institute of Intellectual Co-operation, sponsored by the League of Nations. This was a collection of essays by men of different political persuasions, all concerned to put the European cultural heritage at the service of society. Mairet, warmly approving, gave the impressive list of those involved: Valéry himself, Henri Focillon, Salvador de Madariaga, Miguel Ozorio de Almeyda, Alfonso Reyes, Einstein, Freud, and Gilbert Murray. He was not however impressed by the consortium's claim to be "non-political". Intellectuals in his view should "get a grip on reality", and he welcomed the dissenting voice of the Mexican Reyes, who spoke out for active participation in "the social unrest of our time", and argued that the League should be the context of that participation (Mairet 1933: 231-232).

Through the London PEN Centre, especially after her election to the PEN Executive Committee in October 1934, Jameson would meet Mairet frequently. She was already making her voice heard in PEN in defence of European colleagues, and for the development of the right kind of Europe. In January 1934, she began to deluge Hermon Ould (Jameson 1930-39) with letters urging him to mobilise PEN on behalf of the imprisoned left-wing writer and journalist Ludwig Renn, a vociferous opponent of Hitler, whose name had been raised at the May 1933 International PEN Congress in Dubrovnik, along with others such as Karl von Ossietsky, Erich Muehsam, Sigmund Freud, and Heinrich Mann.

\section{THE ROAD TO SPAIN}

From a distance, Jameson had already looked over into Spain. On holiday in France in the Spring of 1931, she was with her son Bill in the Basque region of France, visiting the flooded caves near Sare on the Spanish frontier. It was, she notes in her autobiography, the day after the abdication and flight of the King of Spain, and her dry comment on the peasant guide who shared his lunch with them makes clear where her sympathies lay:

As we ate it with him, he talked with sharp gaiety about the fall of kings.

"For me," he said, smiling, "they cannot drop off too quickly". 
Lifting a hand the colour and texture of a ripe walnut, he wiped them off the end of his long Basque nose. (Jameson 1984a: I, 262)

Her next recorded visit was another holiday. In March 1935, she went with her second husband, the historian Guy Chapman, to Tossa, on the Catalan coast north of Barcelona (I, 333-335). At that time, Tossa was still a small fishing port, unchanged since the Middle Ages, but already fashionable with English artists and writers. They were there for five weeks, from March to April, sharing the village with a handful of German refugees and a band of English female artists. There was just the one hotel, run by a Swiss and a German Jewish exile, a quiet headland, harbour, stony soil, empty streets, and the sea covered with fishing boats. Jameson records finding there the image that focused the theme of In the Second Year, the novel of English fascism that she had been meditating since hearing the American journalist Dorothy Thompson give an account of the Night of the Long Knives, Hitler's murderous despatch of his rivals. What she wanted to know was what motivated a dictator to kill the men who helped put him in his place. The unspoken homosexual tension binding together two Spaniards, caught in the lamplight at their table, both attachment and hostility, was the perfect emblem for the relationship she would explore between her English dictator and the soldier friend who brought him to power.

In her account in Journey from the North of these happy, creative weeks, there is no mention of the intense Republican and Communist activity for which, according to the pro-Franco poet Roy Campbell, the Catalan coast was notorious, nor the plethora of German Jewish refugees who had settled there, fleeing Hitler, or the British novelist who was, Campbell (1951: 318-319) said, "in the racket". She cut from the first draft of her typescript an anecdote about a visit from the writer Ralph Bates, a Communist Party member, who in James Hill's novel would feed into the figure of the British novelist, Turnbull, a gluttonous, arrogant womaniser who is also a loyal political commissar. Bates, according to the typescript (Jameson [n.d.]: 88), ate with them in their hotel, told them about the imminence of civil war, which would be, he said, a workers' war, and offered to find a use for her writing, as an independent voice outside the Party. He had been brought to the Chapman's flat the year before by Lilo Linke, one evening in 1934, to join Philip Jordan and Nye Bevan at dinner and enlighten them all about Spain: "It's the only country where the movement has kept its soul. Poverty and hard living

2. 14th April 1931, following the elections in which socialists and liberal Republicans won almost all the provincial capitals, Alcalá Zamora became President of the Republic and Alfonso XIII fled from Spain. 
- that's the secret. You won't see any Labour leaders there stuffing themselves in the Ivy" (Jameson 1984a: I, 316).

On her return from Tossa, she wrote In the Second Year, and then completed None Turn Back (1936), the last volume of her trilogy on the 1920s and the collapse of the General Strike. Spain, though never mentioned in the first and only briefly referred to in the second, is an underlying inspiration in both texts. They may seem to be set uniquely in English perspectives, but the Spanish example is there to help trace the nature of emergent Fascist violence, and to show the forces ranged against revolutionary ideals. In None Turn Back, lessons learned in Spain have formed the understanding of Henry Smith, the labour organiser. He appears for the first time in Love in Winter (1935), briefly characterised as a survivor of Class 1914, who has spent four formative years after the war as a labourer, a lorry driver, and a waiter, in Spain and Germany, and bears witness to the brutal poverty of the slums of Barcelona and Hamburg (Jameson 1984b: 349). In None Turn Back, as he drives towards London to his work on the Strike Committee, a flash of memory, specific and detailed, links the resistant poor of Spain and England in a shared oppression, joining the prisons of Barcelona to the industrial landscape of the London suburbs:

[A] friend of his, a workman from a town near Barcelona, had all his toe- and finger-joints broken in the prison of Montjuich, one a day, to teach him not to be discontented with his lot. The sunlight of Barcelona quivered behind his eyes, blinding him, thrown back from the whiteness of the walls. His friend held out one of his maimed hands in the most curious way, as though it did not belong to him.

He came back to the tepid light and air of the West Road. A modern factory, as white as the house near the harbour in Barcelona in which he had lived then, but less dazzling, was on his right hand. Another near it was half built. They were both hideous, like a white leprosy on the once green fields of this part, just what you would expect a rich firm to put up in 1926, with no organ of taste and no instincts. (Jameson 1984c: 112)

Another personal connection with Spain developed in the mid-1930s. Two months after Jameson finished writing None Turn Back, in March 1936, Guy Chapman went out to Málaga, to spend five weeks with his old friend Sir Peter Chalmers Mitchell, a fellow-member of the Savile Club (Chapman 1975: 151-155). Chalmers Mitchell was an impressive, eccentric English character. During the First World War, he was attached to the department of military intelligence at the War Office. A biological scientist, he eventually became Secretary of the Zoological Society of London, up to his retirement in 1935, when he moved out to Málaga 
to live in the villa Santa Lucia that he had bought in March 1933. Knighted in 1929, he was also a Fellow of the Royal Society, and he wrote journalism for the Times. From Chalmers Mitchell, an establishment figure with an ardent, non-party commitment to social justice that led many of his peers to dismiss him as a Communist, the Chapmans received first-hand accounts of events in Spain.

Chalmers Mitchell was already in the country when the Republican government took over in 1931. They were, he says, a respectable group of people, and he heard no talk of Bolshevism, Russian influence, or Spain "going red" (Chalmers Mitchell 1938: 27). He considered the Constitution passed at the end of 1931 to be a liberal one, "radical in its reforms but with no trace of communistic theory" (34). Everything he saw in 1932 indicated to him that the British press was not telling the truth about Spain. Civil order was being maintained, there was no suppression of the Church, and no burning of churches.

When Chapman was with him in 1936, Chalmers Mitchell saw no signs of disturbance, and the only intimation of what was to come in July came from the house of his wealthy, snobbish neighbours, the Bolins, who were busy bricking up their wooden gates and replacing them with a steel wicket (87). Chapman, a dyedin-the-wool Tory, noted that in Málaga: "There was an on-and-off strike, and the walls were covered with the hammer and sickle. Even in the country, the filth was unbelievable." On the drive out to spend a day in Ronda, they passed a group of peasants, "who raised their fists and shouted. Their village [...] was one of the most desolate and decrepit I had seen, even in southern Spain" (Chapman 1975: 153154). Chalmers Mitchell stayed in Málaga as events unfolded, providing support for members of the British colony and a refuge for the ungrateful Bolins, and establishing good terms with the anarchist leaders, who, according to Chapman (164), "made a pet of him". In October 1936 he published a letter in the Times describing the true state of affairs in Spain. He was in Málaga during the siege, at the beginning of 1937, and was arrested by the rebels along with Arthur Koestler, who was sheltering in his villa. He was quickly released, with the consul's intervention, and evacuated back to England in a Royal Naval destroyer. He was made to sign the Official Secrets Act, and he was shocked and disappointed by the reactions of former British residents, who shunned him as a traitor. In My House in Málaga, referring, one assumes, to In the Second Year, he wrote of the pessimism about England's future he now shared with his friend's wife:

I fear that Margaret Storm Jameson was correct in her anticipation of a successful Fascist rising in England. All the ordinary ties of decency, friendship and even family relationship will disappear and those who do not accept the new order 
with some pretence of enthusiastic acquiescence must be prepared for a sadistic violence. (Chalmers Mitchell 1938: 308)

On 5th March 1937, Jameson wrote to her friend Hilary Newitt Brown:

Guy's friend Peter Chalmers Mitchell is back from Malaga, having been saved from shooting at the last minute. He can't talk, because they'll shoot his servants if he does, but he is privately full of bitterness and stories of the usual Fascist foul conduct. Malaga was taken by the Italians, of course. The Spaniards didn't arrive until the next day. France next, I suppose. Someone, I think Mitchell, said in four months. (Jameson 2007: 170)

The same letter refers to the return of Guy's friend, the journalist Philip Jordan, from Spain: "Guy saw him for a minute, and says he is very gloomy - about the disorganisation, lack of control, and the imminent food shortage - there is an arms shortage too, of course. He's coming down here soon and I'll get more news".

In September 1937, Chapman went out to stay with Chalmers Mitchell again, to help him drive to the Pyrenees, where he wanted to talk to Ramón Sender, whose novels he was translating (Jameson 1984a: I, 358; Chapman 1975: 164-168). Chalmers Mitchell was writing his autobiography at the time, Chapman records, and although Chapman gives no details of their conversations on events in Spain, it can be assumed that much was said, not least during the five days in Pau they spent with Sender.

Jameson's next contact with Spain came through her work with PEN (the international association of Poets, Essayists and Novelists) on behalf of the refugee writers fleeing Hitler. By this time, she was President of the London PEN Centre, and working with the PEN Secretary, Hermon Ould, to organise permits and funding. On 22nd February 1939 (London PEN Centre: 1937-43), the London Executive Committee noted an appeal from a Monsieur Obiols, sent from Toulouse, who was accompanied by thirty-one members of the Catalan Centre in flight. Ould was delegated to go to Paris and interview any who had already arrived there, and plans were made to raise funds for them. A Catalan Centre in Exile was established in London, under the leadership of Josep Batista I Roca and Carles Pi Sunyer, and there were many opportunities for collaboration. At the PEN International Congress of September 1941, on "Literature and the World after the War", the two Catalan representatives were to speak out for the common European values the conference aimed to promulgate: a common heritage, shared intellectual values, and the ideal of the free mind. They defended nationalism, and the richness brought to the European community by national variations, but nevertheless argued passionately for that community of culture in which, they said, 
individual national differences could flourish ("Nationalism and internationalism are not incompatible: each is the complement and mainstay of the other" [Batista I Roca and Pi Sunyer 1942: 122]).

Not until the Second World War was over did Jameson give any prominence to Spain in her own writing. The Green Man (1952), her epic narrative of the reconstruction of English values in the twentieth century, returns to Tossa to understand what Spain meant to the politically innocent young Englishmen who went out there in the early 1930s, seeking pleasure and finding a whole new world of difference. The hotel is the same as she describes in her autobiography, with the same inhabitants. In the late Spring of 1935, Andrew, the son of the English manor, and his friend Robert, both members of Auden's generation at Oxford, learn for the first time what living really means, and what it can cost:
A hard simple sensual happiness of warm sand after cold battering waves, the scent of herbs and wood smoke, the scorching light, the darkness and its chorus of cicadas and frogs. They lived, completely content, in their bodies - it was as if, in this light, bodies became porous to the least vibration of the air.
There were other vibrations here - of poverty and anger. They got those clearly enough. A selfish instinct turned both young men away from them. Time enough for that. (Jameson 1952: 168-169)

They may be reluctant to acknowledge that the wrongs, and the conflicts here, are theirs as much as the life of body in landscape, but the lines are already being drawn:

A sun-blackened fisherman asked Robert abruptly if it was true that England and Germany were allies. "No, a lie," Robert said.

"A good thing," the Catalan said drily. (169).

There is a great deal here of that "Spanish myth - or metaphor" which Jameson had identified and admired in the short stories of Ralph Bates, "in which even before the civil war, before Guernica, Spain began to be identified with contempt for luxury and death, and the instinct to revolt" (Jameson 1984a: I, 316). But there is also something more serious: an admission of England's guilt towards Spain, for the failure to stand together with the Republic for the values both claimed to uphold. Young Robert's vehemence atones for his elders' treachery, and the narrative will shortly record his return to Spain to fly planes against Franco. Andrew, like Jameson, let what was happening in Spain slip to the edge of his awareness. There is here a sense of personal guilt. On 15th April 1937 Jameson had closed another letter to Hilary Newitt Brown with the bald declaration that "I am against 
valuable people getting themselves killed in Spain. There will be a fiercer fight here than even that is being - and they will be missed" (Jameson 2007: 173).

The story brings the two friends together again as England waits for her own war, against Hitler, to be declared. Writing in the early 1950s, in the Cold War, Jameson (1952: 222), through Robert, denounces Spanish Communists for betraying and torturing socialists, with the same vehemence as she attacks capitalism, and "the brutes who destroyed Guernika" (Jameson had seen Picasso's painting in Paris in 1938). Yet Robert emerges from his Spanish experience with the conviction that "the barbarians - fascists, communists, what you like - defeat themselves" and "one thing a war does for you - persuades you that human beings are decent” (223).

\section{NO VICTORY FOR THE SOLDIER}

If Jameson said little about Spain in her own name, James Hill had a great deal to say about what the country's struggles meant for modern Europe, and what roles artists and intellectuals had to play there, in the struggle against fascism.

The novel has direct relevance to Jameson's own concerns, personal and political, as well as aesthetic, though the experiences and feelings it explores are represented at several removes. Politically, the novel resonates with her concern about Czechoslovakia. It was finished in August/September 1938, just after the Munich crisis and Chamberlain's abandonment of the Czechs, and shortly before Hitler entered Prague. It is full of Jameson's desire to atone for her government's derelictions, and her desperate faith in the transformations individuals might yet bring to a world disappearing under a rain of fascist bombs. Aesthetically, the tragic heroism of the Spanish Civil War provides the ideal context for her exploration of the capacity of modernist art, or rather, modernist artists (the Auden generation) to speak in the name of the future of the common man (Birkett 2007). The bullet that cut short Knox's career, and ended his chances of producing the brilliant and original music of which he knew himself capable, foreshadowed the bullets of the coming world war, in which the need for practical action put a stop to Jameson's own most radical experiments in fictional form.

The novel was well received. It was singled out for special commendation by the Times, the Observer and other leading papers. On the dust-jacket of the American edition, Wilfred Gibson was quoted from the Manchester Guardian, writing in praise of "a surprisingly accomplished first novel"; the Times Literary Supplement had described it as "Vivid, modern, told with such peculiar and compelling force", and the Times had praised its filmic quality ("It has the quick 
portraits, the brief informative scenes, and the rapid dialogue one finds with pleasure in such a film as Remous"). These were techniques Jameson had already begun to experiment with in her trilogy on the 1920s, and the "well contrived irony" praised by John Brophy in Time and Tide, was her trademark. But no-one suspected her authorship. Women, after all, were not expected to write about the noise and the emotions of the battlefield, any more than they would understand the forms and ambitions of cutting-edge modernism.

John Knox, the virtuoso musician and composer, is desperate to make it new ("[W]e're living in 1927, after all"), but as he tells his American journalist friend, Andrew, audiences have no desire to hear a different sound: "[W]hat they really would like is the same old sermons, so that they can go to sleep and not think" (Hill 1939: 126).

In his early youth, he has had one glimpse, in Spain, of a sharply-contoured landscape whose absoluteness for truth matched his own ambitions. A month's holiday in Spain with Andrew, in the Spring of 1923, generates images of unfamiliar, intensely contrasting, scraping harmonies, a closeness to raw truth in which he feels completely at home:

From the first day there he seemed to be walking about his own mind. He recognised towns, harbours, mountains, of a region he had not seen until now. They could have been his thoughts, reshaped in stone or barren ground. There was a peasant dragging a harrow across a field no larger than a small room; there were burning noons; a sky as empty as a skull, as wide as death; stony hills clothed with thyme and lavender; icy dusks made deaf by cicadas; a wind rasping the teeth: and these were a climate he knew already. He felt extraordinarily alert and well. (98)

But the need to learn his trade, and make a living, assigns his life for the most part to the great cities of Europe. He makes his reputation in Europe, struggling to find a form for metropolitan reality. He watches the encroachments of Germany and the spread of Nazi values, and makes his own individual acts of resistance to the tide, defending the poor men he meets, especially poor Jews, and finally deciding that he would be prepared to fight German fascism in defence of France. His great opera for the common man, The Night of Sancho Panza, gives form to his intuitions of the war that will come, in which working people will finally rise against the armies of capital. Tellingly, the figure that for him embodies the oppressed working man is Spanish, simultaneously the representative of the modern proletariat and one of the great archetypes of European culture: 
[W] hat came to him when he saw Sancho Panza in a dark street in Bordeaux, Private Sancho Panza, 291108 Panza, the poor bloody infantry, O, O, O, it's a lovely war, what price peace, no hands wanted, no-bloody-thing which ever way, was first and most sharply a sense of danger. It gave him the last two scenes of Act III, which, later, the critics labelled "prophetic". So they are. But does any ass think that Knox was prophesying a war in Spain? If he had the future in his ears it was a future to which war in Spain is only the anteroom and dumb show, like the dumb show of these scenes - the conspirators, factory owner, politician, recruiting sergeant, whispering head to head in the thick black shadow thrown across the square by the church, Sancho listening bewildered, and at last, at last, remembering whereabouts under the mud floor of his room he had hidden the night's long rusty spear. (246-247)

But it is not a directly political impulse that takes him to Spain, but his own experiences of loss and failure; he is looking for renewal through anonymity and action (270).

Commitment to action will bring him the insights that will enable him to give body in his music to the form of reality lived by ordinary people, and their sufferings and desires. This war is a place where the highest ambitions of threatened European culture could yet be retrieved. In a hospital, Knox meets a dying Republican soldier, a German Jew, a former musician thrown out of his orchestra in Berlin. The man is consumed with anxiety for the safety of a newlydiscovered 16th-century manuscript of lute music, rotting in the cellars of a house under bombardment; Captain Salvador, the Communist Republican who fights on under intolerable pressure, attempting to train officers and organise an army without modern weapons, tools, infrastructure and organization, goes without hesitation to rescue it.

The last quarter of James Hill's book is devoted to Knox's journey through the Civil War. At the beginning of July, he drives to San Rafael with Andrew, who wants to check the rumours that something serious is about to happen to the Liberal government. When the uprising begins in Morocco, they move to Madrid, and Knox drives Andrew to make notes on the fighting behind the town of Guadarrama. To his own surprise, he asks a chance-met staff officer for a job driving an ambulance, and his initiation begins.

The form of Jameson's account mirrors the fragmentary nature of the front. The scene shifts rapidly, over a mixture of vignettes and cameos, brief encounters on and around the battlefield, across roads, fields and hillsides, or in the crumbling buildings of cities shaken by bombs. The language is simple, clinical and vivid, objectifying emotion through accounts of action and perception, 
interspersed with short, sharp dialogue, and dissecting with orderly precision the nightmare relationships between men and the landscape in which their history is written. The nearest model is the stylised realism of Stendhal, or Flaubert, taking his scalpel to his own heart. Knox drives up to establish a first-aid station in the countryside around a Madrid under siege, into confusion shot through with flashes of clarity, a nightmare narrated as bald normality. Here human suffering is one with the landscape:

The heat and the smell made him dizzy and whenever he had time he crawled a little way along the embankment, keeping in the ditch. He noticed the sharpness everything had in the sun, hills, olives, the features of wounded men. The first enemy airplanes came over in the afternoon. They dropped bombs around the bridge and along the line. An orderly was killed and another badly wounded.

"Ours will come next," the doctor said. (283)

The bombing of Madrid, starting with the workers' quarters, is documented with the same stripped-down detail and carefully-rhythmed syntax, and in the same matter-of-fact tones:

The streets here were narrow, the houses old and crowded with families, so that one bomb did more damage and the property destroyed was worth very little anyway. One day they killed thirteen children, and on another three hundred and nine, and there were funerals of children every day during this time. The big bombers were white in colour, the right colour for the funerals of children. (295)

The lines of men streaming on their different purposes across the countryside are choreographed with ruthless simplicity. As the rebels draw closer to Madrid, "Various highly placed persons found it necessary to leave for Valencia next morning on errands suddenly invented. As they left Madrid by the east other men, mostly in boiler suits, many of them without a rifle, were tramping out of the city in another direction (...)" (286).

Expressionist play with light and dark fixes the tragedy enacted in these processions. Driving out to collect the wounded, through deserted streets raked by artillery fire, Knox passes the silent columns of more men going out to fight, "their shadows falling sharply in the November sunlight beyond the shadow of the wall" (290).

Other tragedies, less elegiac, are harder to represent. A soldier from a village near Lorca describes how he and other young men, leaving for the front, first shot all the men of the only wealthy family, to prevent betrayals. Afterwards, they calmed the women and children, took away the bodies and washed down the 
yard. Knox muses that the last detail makes the story bearable: "Men are still human when they can remember certain things" (307).

Knox is forced by illness to leave Madrid, but is determined to return to Spain, whose high, flat landscapes, raked by the extreme forces of nature, are the raw material from which he can compose his new music, "more precise, more taciturn and more common" (331). He goes back to work with the Basques in Bilbao, as secretary and assistant to Aronategui, a captain of the Sanidad Militar, and in this beleaguered and marginalised people, humane, reasonable, courageous and decent, he finds the last repository of Spanish and European values (338).

Knox came to Spain in search of knowledge: "Suffering is a fact. It may be the ultimate fact - existence itself. . . . [...] What I want is to know the fact. I need to live it so that I can report on it afterwards" (291). In the Basque country, suffering is absolute. Driving back from the front line, Knox is bombed by Heinkels, and takes refuge in a bomb hole. Two miles further on, he comes across a peasant standing by a smashed cart at the side of the road, dazed by the loss of all he has, but accepting his loss as part of life "as much as the sun, the fields, his body" (342). Such serenity, accepting loss and continuing, by-passing despair, is the inspiration for the new music Knox now begins to conceive: an opera with the proportions of the great medieval cathedrals, anonymous in its origins, all-inclusive in the community of persons and interests it will reach out and create (346-347)

Knox's vision is rhetorically wild. Its grandiosity carries Jameson's implied critique of the artist's hubristic ambition, and the callousness to others' pain that is a necessary part of the creative process. Ironically, the more clearly Knox can formulate his vision, the more impossible its realisation becomes. Aronategui comes to him to report more air-raids, and to acknowledge that the consequences of political inaction, in Spain and abroad, are finally irrevocable, thanks to the foot-dragging of the Communists in Valencia and the non-interventionist policies of the English government (347). A letter arrives from Andrew, telling him that The Night of Sancho Panza is to be staged in London in 1938. But the message of the opera will arrive too late. The same letter attacks the British government for its slowness in taking in the Basque child refugees, its reluctance to accept more than four thousand, and its insistence on charging with interest (32.5 per cent a year, Andrew calculates) for the cost of equipping the Basque camp (Hill 1939: 353; and see Basque Children [n.d.]). The gap between the artist's ability to find the right forms to communicate his meaning, and the potential for his work to make a real political difference, is unbridgeable.

German planes machine-gun the streets of a starving Bilbao, and a stream of refugees pours out onto the river. The exhausted Knox feels the forms of his 
music at last coming through, and is ready to go away and create his great, worldtransforming message of the vivifying strength of the common man. But he has stayed too long inside the reality he wanted to report. He is accosted in the streets of the dark town, shot by an excited anarchist, and left for dead. In a tense and elegiac final sequence, he is driven away by his young American friend, Bill Hedley, along a road streaming with militiamen ("the road was dark with them and the dust they raised"), himself now part of the human procession. He draws his last breath in front of a farm house, twenty miles away from Bilbao, in Hedley's arms. His last perception is of that essence of human suffering that it was his ambition to capture in his music: the grief of the human condition, in which he is at last both observer and participant. It's a grief that is both personal and universal, a particular moment of historical loss (the fall of Bilbao) and the loss everyone experiences (home and mother), all shot through with the fury of humanity at the injustice of the universe:

He saw Bill's face - he was crying. Some odd duality of sense made him hear the grief he could only just see; it was a phrase of four low notes. Something must have happened to Mike, he thought. He wanted to ask him whether that was it, or whether he was crying because Bilbao had been lost. His sight sharpened suddenly. He saw Bill, looking angry now, the tears running over his cheeks, and behind him the white wall of a house and a woman's black knitted shawl. (Hill 1939: 363)

Knox's story is intensely ironic. The artist in search for new forms to represent the new realities of his generation must himself experience those realities; but the experience will destroy him, and the ideal work of art will never be realised. The most that can be achieved are figures of knowledge, and sharpened perception: tears on a human face, the desire to know why, and the images of lost home.

On 5th November 1938, Jameson (2007: 183-184) wrote to Hilary Newitt Brown of her feelings as she emerged from the "stunned misery" of Munich. Some of her friends were completely defeatist, but others shared "my own feeling of halfexhilaration", and her notion that "maybe it is the beginning of the beginning". Yet the situation was dire. She was working through PEN to get the German and Austrian refugees out of Prague, against a resistant Home Office, and wracked with anxiety for "the ocean of threatened people, Jews, socialists, social democrats, communists". France was in "the most awful mess", and the arch-appeaser threatened Britain's future: "Chamberlain will probably defeat us all". As for Spain:

Spain is on the mat now. Even before you get this, some filthy game will have come clear into the open. I'd like to have the writing of the history of this period 
in about fifty years time. If there is any one left to write any history or anyone able to read it.

James Hill had just published a first stab at writing that history. He hadn't stinted his denunciations of the filthy games that had brought about Spain's destruction and prepared the way for the shabby mess through which Europe was now picking its way. But equally, he had set out what Spain had been fighting for, and what the artist Knox had come to defend: clarity of vision, compassion and resistance. That understanding, perhaps, lay behind the exhilaration sustaining Jameson after the most recent capitulations. In Derio's words: "Here we still cared more for human beings than for anything they can make or possess. All our values were human ones" (Hill 1939: 341).

\section{REFERENCES}

Basque Children. [n.d.] URL http://www.spanishrefugees-basquechildren.org/C1Basque_Children.html.

Batista I Roca, J. M. and Carles Pi Sunyer. [1942]. "European Unity and the Smaller Nations." Writers in Freedom. Ed. Hermon Ould. London: Hutchinson \& Co. 120-126.

Birkett, Jennifer. 2007. "A Fictional Function: Storm Jameson and W. H. Auden." English: The Journal of the English Association. 56 (215): 171-185.

Campbell, Roy. 1951. Light on a Dark Horse. An Autobiography (1901-1935). London: Hollis \& Carter.

Chalmers Mitchell, Peter. 1938. My House in Málaga. London: Faber and Faber. Chapman, Guy. 1975. A Kind of Survivor: A Memoir. Ed. Margaret Storm Jameson. London: Gollancz.

Hill, James. (Pseudonym of Margaret Storm Jameson.) 1939 (1938). No Victory for the Soldier. New York: Doubleday, Doran \& Co., Inc.

Jameson, Margaret Storm. 1928. Farewell to Youth. London: William Heinemann Ltd. Jameson, Margaret Storm. 1930-39. Letters from Storm Jameson to Hermon Ould. PEN Archive. Ms (PEN). Recip. Jameson, Storm. 3rd Folder 1930-39. The Harry Ransom Humanities Research Center, The University of Texas at Austin.

Jameson, Margaret Storm. 1936. In the Second Year. London: Cassell \& Company Ltd.

Jameson, Margaret Storm. 1952. The Green Man. London: Macmillan \& Co. Ltd. Jameson, Margaret Storm. 1984 a (1969-70). Journey from the North. 2 vols. London: Virago Press. 
Jameson, Margaret Storm. 1984b (1935). Love in Winter. London: Virago Press. Jameson, Margaret Storm. 1984c (1936). None Turn Back. London: Virago Press. Jameson, Margaret Storm. 2007. "Letters to Hilary Newitt Brown." Eds. Chiara Briganti and Kathy Mezei. In Margaret Storm Jameson: Writing in Dialogue. Eds. Jennifer Birkett and Chiara Briganti. Newcastle: Cambridge Scholars Publications. 165-206.

Jameson, Margaret Storm. [n.d.] Typescript of Journey from the North. Vol. 2. Jameson, Storm. Works (Autobiography). The Harry Ransom Humanities Research Center, The University of Texas at Austin.

London PEN Centre. 1937-43. Executive Committee Minute Book. PEN Archive (uncatalogued at time of consultation). The Harry Ransom Humanities Research Center, The University of Texas at Austin.

Mairet, Philip. 1933. "Views and Reviews. A League of Minds." New English Weekly III (10): 231-232. 
